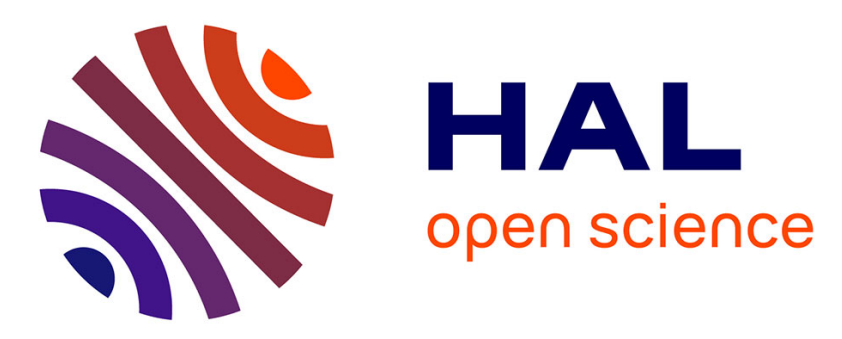

\title{
Wetland monitoring: aquatic plant changes in two Corsican coastal lagoons (Western Mediterranean Sea)
}

Pasqualini Vanina, Christine Pergent-Martini, Catherine Fernandez, Lila Ferrat, Jean E. Tomaszewski, Gérard Pergent

\section{- To cite this version:}

Pasqualini Vanina, Christine Pergent-Martini, Catherine Fernandez, Lila Ferrat, Jean E. Tomaszewski, et al.. Wetland monitoring: aquatic plant changes in two Corsican coastal lagoons (Western Mediterranean Sea). Aquatic Conservation: Marine and Freshwater Ecosystems, 2006, 16 (1), pp.43 - 60. 10.1002/aqc.691 . hal-01769109

\section{HAL Id: hal-01769109 \\ https://hal.science/hal-01769109}

Submitted on 17 Apr 2018

HAL is a multi-disciplinary open access archive for the deposit and dissemination of scientific research documents, whether they are published or not. The documents may come from teaching and research institutions in France or abroad, or from public or private research centers.
L'archive ouverte pluridisciplinaire HAL, est destinée au dépôt et à la diffusion de documents scientifiques de niveau recherche, publiés ou non, émanant des établissements d'enseignement et de recherche français ou étrangers, des laboratoires publics ou privés. 


\title{
Wetland monitoring: aquatic plant changes in two Corsican coastal lagoons (Western Mediterranean Sea)
}

\author{
VANINA PASQUALINI ${ }^{\mathrm{a}, \dagger, *}$, CHRISTINE PERGENT-MARTINI $^{\mathrm{a}, \dagger}$, CATHERINE FERNANDEZ $^{\mathrm{b}, \dagger}$, \\ LILA FERRAT $^{\mathrm{a}}$, JEAN E. TOMASZEWSKI $^{\mathrm{a}}$ and GÉRARD PERGENT ${ }^{\mathrm{a}}$ \\ ${ }^{a}$ University of Corsica, Faculty of Sciences, Equipe 'Ecosystémes Littoraux', BP 52, 20250 Corte, France \\ ${ }^{b}$ LBEM-IHEP (UMRCNRS 6116) University of Provence, St Jérome Case 421, 13397 Marseille Cedex 20, France
}

\begin{abstract}
1. A monitoring system was developed in two Corsican coastal lagoons (Biguglia and Urbino; Corsica, Western Mediterranean).

2. Three species of seagrass (Nanozostera noltii, Ruppia cirrhosa and Cymodocea nodosa) were monitored by (i) measuring spatio-temporal changes in the seagrasses, using fixed structures, (ii) investigating temporal changes in the biological parameters of the seagrasses, and (iii) mapping their distribution by processing aerial images of both lagoons.

3. These investigations showed that, while the two lagoons exhibit, a priori, a certain structural homogeneity (ecosystems based on aquatic plants), they function in different ways that are specifically linked to environmental conditions.

4. At present, the estimated net production varies from 86 to $469 \mathrm{~g} \mathrm{Cm}^{-2} \mathrm{yr}^{-1}$ at Biguglia and 190 to $1301 \mathrm{~g} \mathrm{C} \mathrm{m}^{-2} \mathrm{yr}^{-1}$ at Urbino. These values confirm the richness of these two lagoons, and the interest of using seagrass, by means of regular monitoring, for the conservation and management of coastal lagoons.
\end{abstract}

KEY WORDS: coastal lagoon; Mediterranean; seagrass; monitoring; mapping; population dynamics

\section{INTRODUCTION}

Wetlands are important reservoirs for biodiversity. Wetlands perform various functions that are essential to the life of the organisms that are dependent on them (feeding, reproduction, shelter, refuge and rest). These biological functions give wetlands a distinctly higher productivity rate than other environments (Kjerfve, 2000). Wetlands also contribute to the maintenance and improvement of water quality by acting as a purifying filter, since they favour the deposition of sediments and the trapping of toxic elements, and are also a favoured site for biochemical degradation (Kjerfve, 2000).

*Correspondence to: V. Pasqualini, University of Corsica, Faculty of Sciences, Equipe 'Ecosystémes Littoraux', BP 52, 20 250 Corte, France. E-mail: pasquali@univ-corse.fr

$\dagger$ egal contribution to the work 
Aquatic macrophytes, in particular aquatic angiosperms, constitute a major component of lagoonal ecosystems (Millet and Guelorget, 1993; Sfriso and Ghetti, 1998; Sfriso et al., 2001, 2003; Duarte et al., 2002; Menéndez, 2002; Marzano et al., 2003). These plants are of particular interest in view of their ecological (Tamisier and Boudouresque, 1994) and economic roles (Pearce and Crivelli, 1994; Skinner and Zalewski, 1995). They also contribute to the sedimentary balance (Skinner and Zalewski, 1995) and constitute a bioindicator of water quality (Succow and Reinhold, 1978 (in Blandin, 1986); Meriaux and Wattez, 1980; Guilizzoni, 1991).

Currently, the development of various human activities (e.g. the exploitation of living resources, industrialization, urbanization and fishing) affects the stability and conservation of lagoonal ecosystems and, in some instances, seriously jeopardizes their future survival (Bacher et al., 1995; Bettinetti et al., 1996; Herrera-Silveira, 1996; De Casabianca et al., 1997; Deslous-Paoli et al., 1998; Kjerfve, 2000). Wetlands are extremely fragile and threatened; almost a million hectares have been destroyed over the past 50 years (Ramade, 1990). Although they are registered in Annexe I of the EU Habitats Directive as a priority habitat, and some of them are on the list of sites covered by the Ramsar Convention, Mediterranean lagoons are rarely truly protected, and their destruction continues. Numerous studies have reported the degradation of vegetation (Montague and Ley, 1993; De Casabianca et al., 1997), the deterioration of physical and chemical parameters (e.g. salinity, turbidity, silting; Souchu et al., 1997, 1998; De Casabianca and Posada, 1998), or even the infilling of lagoons (e.g. wetlands of St. Florent - Corsica, France). While a few lagoons enjoy specific protective measures (e.g. Camargue Natural Reserve - France, Ebro Natural Park - Spain, Ichkeul National Park - Tunisia; Carasp, 1997), this does not necessarily ensure their actual conservation. In addition, the few attempts at lagoon rehabilitation that have been undertaken over the past 20 years (Pergent and Ben Maïz, 2001), have shown that this involves long and costly procedures with a highly uncertain outcome (Vidy, 2001). It is thus vital to develop tools for the effective management and protection of these remarkable sites, before irreversible degradation occurs.

Within the Mediterranean Basin, Corsica (an island in the Western Basin) is of particular importance, with more than 50 coastal lagoons, covering 3000 hectares (Pergent-Martini et al., 1997). Given the importance of aquatic angiosperms in these lagoons (i.e. Cymodocea nodosa (Ucria) Ascherson, Nanozostera noltii (Hornem.) Tomlinson, Ruppia cirrhosa (Petagna) Grande; Pergent-Martini et al., 1997; Agostini et al., 2003a), it seemed necessary to develop a monitoring system based on patterns of distribution and change in the seagrasses, for two of the major lagoons of the east coast of the island. The aims were (i) to diagnose the state of these lagoons in order to establish a baseline reference state, and (ii) to initiate an ongoing survey which will provide a basis for the proper management and conservation of these sites.

\section{MATERIALS AND METHODS}

The two sites chosen (Figure 1) show distinct differences regarding both their typology (depth, salinity) and the human pressures to which they are exposed (Table 1). The Biguglia lagoon (Figure 1) is linked to the sea by a channel to the north, and a channel to the south. A mesohaline type lagoon (Sacchi, 1985; Table 1), it is characterized by high inputs of freshwater in the southern part (e.g. $60 \%$ to $140 \%$; Frisoni and Dutrieux, 1992). The sedimentological profile is classic, with fine sediment, rich in organic silt, in the centre and on the continental shore, and coarse sandy sediment, sometimes shelly and giving rise to beaches, near the lido (Agenc, 1989). The lagoon is mainly used for fishing, with a mean annual production of $180 \mathrm{t}$ of fish (Boulmer et al., 1997). The Urbino lagoon (Figure 1) is linked to the sea by a regularly maintained channel in the north-east (Clanzig, 1992). A euryhaline lagoon (Table 1; Sacchi, 1985), it is characterized by the high degree of homogeneity of its water mass (except at the river outlets, in the north-west sector). The bottom consists of silt, rich in organic matter (Longere et al., 1972), sand and terrigenous or shelly sediments (Coeurd'acier, 1987). The lagoon is mainly used for aquaculture, with a production rate that varies 


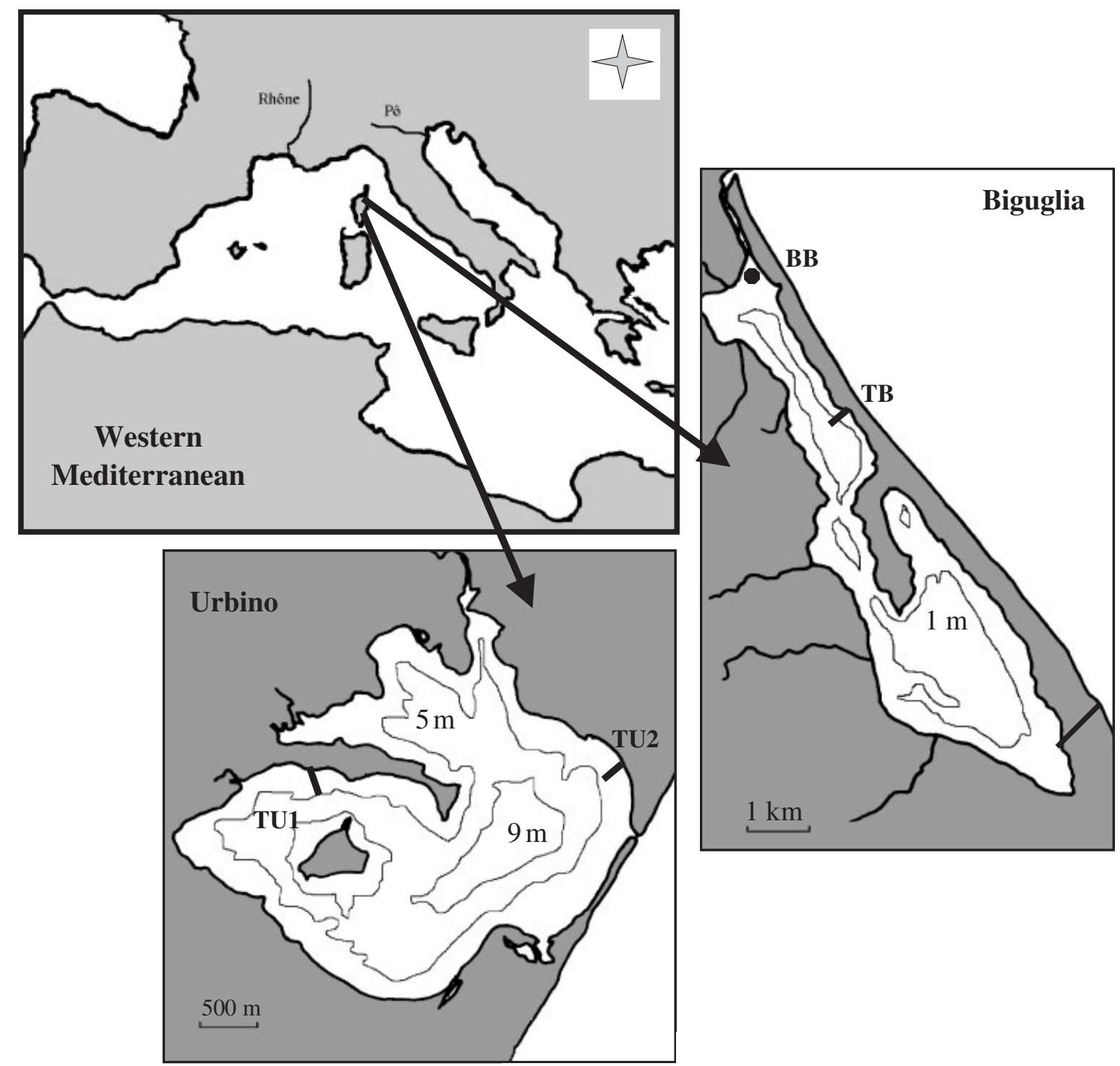

Figure 1. Situation of the Biguglia and Urbino lagoons and monitoring structures (BB, marked survey area Biguglia; TB, Transect Biguglia; TU1, Transect Urbino no. 1; TU2, Transect Urbino no. \#2).

considerably from year to year, both quantitatively and qualitatively. Production rose from $162 \mathrm{t}$ of shellfish and $20 \mathrm{t}$ of fish in 1978, to 200-250 t of fish in the 1990s (Clanzig, 1992). Currently, production has declined, with an annual mean production of $50 \mathrm{t}$ of fish (i.e. Dicentrarchus labrax and Sparus aurata) and $40 \mathrm{t}$ of shellfish (i.e. Crassostrea gigas), together with fishing (seasonal small craft fishing) estimated at $100 \mathrm{t}$ (Pergent-Martini et al., 1997).

The spatio-temporal changes in the seagrasses were investigated by means of fixed structures. Monitoring was carried out using fixed markers, placed in the lagoon in April 1998 and regularly checked each season until April 1999. The markers (metal rods) were positioned along the outer limit of a meadow (marked survey area) or within a stand along a precise axis (transect). Whichever the technique chosen, the aim was 
Table 1. General characteristics of the sites studied (Pergent-Martini et al., 1997)

\begin{tabular}{|c|c|c|}
\hline Lagoon & Biguglia & Urbino \\
\hline \multicolumn{3}{|l|}{ Abiotic parameters } \\
\hline Geographical coordinates & $42^{\circ} 37^{\prime} \mathrm{N} ; 9^{\circ} 27^{\prime} \mathrm{E}$ & $42^{\circ} 03^{\prime} \mathrm{N} ; 9^{\circ} 28^{\prime} \mathrm{E}$ \\
\hline Surface area (ha) & 1500 & 760 \\
\hline Maximum depth (m) & 1.8 & 9.2 \\
\hline Mean depth (m) & $1.5 \mathrm{~m}$ & $5 \mathrm{~m}$ \\
\hline Volume (millions of $\mathrm{m}^{3}$ ) & 38 & 33 \\
\hline Catchment area $\left(\mathrm{km}^{2}\right)$ & 180 & 31 \\
\hline Temperature $\left({ }^{\circ} \mathrm{C}\right)$ & 5 to 26 & 9 to 29 \\
\hline Salinity (\%o) & 4 to 26 & 26 to 44 \\
\hline \multicolumn{3}{|l|}{ Human pressure sources } \\
\hline Population of catchment area (ha) & 18528 & 245 \\
\hline $\begin{array}{l}\text { Industrial and touristic activities in } \\
\text { the catchment area }\end{array}$ & $\begin{array}{l}\text { Effluent, wine-making, airport, oil } \\
\text { tanks, boilerworks, hotels and res- } \\
\text { taurants, transport }\end{array}$ & None \\
\hline $\begin{array}{l}\text { Agricultural activities in the catch- } \\
\text { ment area }\end{array}$ & $\begin{array}{l}\text { Orchards, vineyards, pumpkins and } \\
\text { squashes, stock-rearing }\end{array}$ & Orchards, vineyards (only in parts) \\
\hline Activities at the 'lido' & $\begin{array}{l}\text { Built-up area, holiday village, hotels } \\
\text { and restaurants }\end{array}$ & None \\
\hline Fishing and aquaculture & 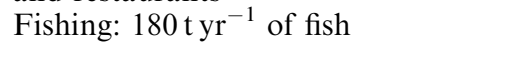 & $\begin{array}{l}\text { Limited fishing Aquaculture: } \\
150 \mathrm{t} \mathrm{yr}^{-1} \text { of fish; } 40 \mathrm{tyr}^{-1} \text { of shellfish }\end{array}$ \\
\hline
\end{tabular}

to record accurately the existing meadows and bottom types in order to perform an accurate microcartographic survey (precision $20 \mathrm{~cm}$ ). Survey markers and a permanent transect were set up in the Biguglia lagoon and two transects in the Urbino lagoon (Figure 1). The survey markers set up in Biguglia lagoon encompassed the unique zone containing Nanozostera noltii (nearness of the channel). Transects set up in both lagoons were established on the basis of the results of preliminary surveys in areas with representative seagrasses (cover, distribution, present species).

In parallel, in situ sampling (five replicates) was carried out by means of a cylindrical corer $(15 \mathrm{~cm}$ in diameter and $50 \mathrm{~cm}$ in height), at a water-depth of $0.5 \mathrm{~m}$, in order to record the seasonal patterns of change in the vegetation. For each sample, we took care to ensure that none of the leaves were cut, by sliding a hand into the corer and arranging them all vertically. These samples were collected from January 1998 to July 1999, in order to determine the state of the plant formations over an annual cycle (January 1998 to January 1999) and initiate a short-term survey (January 1999 to July 1999). In the laboratory, for each core, the density (number of shoots per $\mathrm{m}^{2}$ ) of each species present was determined, then the below-ground tissues (rhizomes and roots) and above-ground tissues (leaf shoots) were separated and oven-dried $\left(48\right.$ hours at $\left.60^{\circ} \mathrm{C}\right)$, and the biomass of each fraction was measured. A study of the main foliar biometric parameters of seagrasses (e.g. length, width, number of leaves; LAI: Leaf Area Index; Coefficient A: percentage of leaves having lost their apex owing to grazing by herbivores or to hydrodynamic action; Giraud, 1977) was added in order to complement the preceding observations.

The distribution of the aquatic angiosperms and bottom types was mapped by image processing of aerial photographs of the Biguglia and Urbino lagoons, according to the method defined by Pasqualini et al. (1997). The photographs, scale 1/10000, were taken in June 1999 (Compagnia Generale Ripresaeree di Parma ${ }^{\circledR}$ ). The resolution was adjusted in order to obtain a $2 \mathrm{~m}$ by $2 \mathrm{~m}$ pixel. The image-processing operation enabled the main meadows and bottom types to be identified, on the basis of the colours in the 
aerial photographs and point-based field data; 150 point-based field data were obtained for each lagoon, from the surface by means of a Calpha bucket when the depth and turbidity allowed, or by scuba diving. The position of each point was recorded using differential GPS (Global Positioning System: Valsat MLR), giving a level of precision of less than the size of a pixel. These point-based field data were used to classify the image-processing and were generalized to the whole of the image, in order to produce the thematic map (Pasqualini et al., 1997).

The comparisons of mean parameters as a function of site or species were processed by the Mann-Witney or Kruskal-Wallis tests (Zar, 1984). The relation between two parameters was analysed using simple linear regression (Zar, 1984). The correctness of the fit was tested by analysis of variance. The software used was Statgraphics plus (v2.1) for Windows.

\section{RESULTS}

\section{Local distribution and temporal changes}

Four species of aquatic angiosperms were recorded in the Biguglia lagoon: Nanozostera noltii, Ruppia cirrhosa, Ruppia maritima Linneus and Potamogeton pectinatus Linneus. Monitoring in January 1999 was ruled out by these aquatic plants' lack of above-ground structures in winter. The survey markers (Figure 2(a)) were positioned at the limit of a monospecific $N$. noltii meadow, at a depth of $-0.8 \mathrm{~m}$. From April to October 1998, a decrease in N. noltii was observed. The limit of the meadow in April 1999 remained short of that observed one year previously $(0.7 \mathrm{~m}$ in the north to $1.8 \mathrm{~m}$ in the south). The seasonal fluctuations were much more marked in the south of the survey area (maximum range of variation $3 \mathrm{~m}$ ) than in the north (maximum variation range $1 \mathrm{~m}$ ). For the transect (Figure 2(b)), in April 1998, a continuous relatively dense Ruppia sp. meadow was observed (up to $50 \mathrm{~m}$ from the shore), with a little Ulva sp. This plurispecific meadow comprised $90 \% R$. cirrhosa and extended from $-1.1 \mathrm{~m}$ to $-1.6 \mathrm{~m}$ in depth. Below that, there was mainly silt colonized to a greater or lesser extent by Ulva sp., which can produce very dense (continuous) formations locally, from 50 to $75 \mathrm{~m}$ from the shore) with a little $R$. cirrhosa. This continuous $R$. cirrhosa meadow disappeared almost entirely, and only reappeared in spring 1999 . It then occupied virtually the whole transect. Within this transect, a few specimens of $R$. maritima and P. pectinatus were observed.

Three species of aquatic angiosperms were recorded in the Urbino lagoon: Cymodocea nodosa, $N$. noltii and $R$. cirrhosa. In April 1998, TU1 crossed a continuous $C$. nodosa meadow that progressively gave way, after $78 \mathrm{~m}$, to a population of Gracilaria dura (C. Agardh), which became very dense beyond $90 \mathrm{~m}$ (Figure 3). This distribution pattern, and in particular the limit of the Cymodocea/Gracilaria, remained relatively constant throughout the study period (Figure 3). Over the whole study period, it was noted that the $C$. nodosa meadow generally occupied the depth range from $-0.4 \mathrm{~m}$ to $-4.5 \mathrm{~m}$ whereas the Gracilaria dura population generally started at $-4.7 \mathrm{~m}$ and went beyond $-5.5 \mathrm{~m}$. In April 1998, the second transect (Figure 3) was mainly occupied by an extended monospecific C. nodosa meadow, which gave rise locally to a plurispecific formation of $N$. noltii (from 5 to $27 \mathrm{~m}$ from the shore). This meadow, which extended to a depth of $-1.5 \mathrm{~m}$, was preceded, at shore level, by a narrow monospecific strip of $N$. noltii. During the study period, these plant formations showed little change. There were only some fluctuations in the strip of $N$. noltii meadow. From October 1998, a new species was observed along the transect, with a few shoots of $R$. cirrhosa.

\section{Characterization of aquatic angiosperms and temporal changes}

Analysis of the density of different species of aquatic angiosperms showed that the values differed according to the species under consideration (Table 2). The densities varied significantly: from 679 to 12903 shoots 


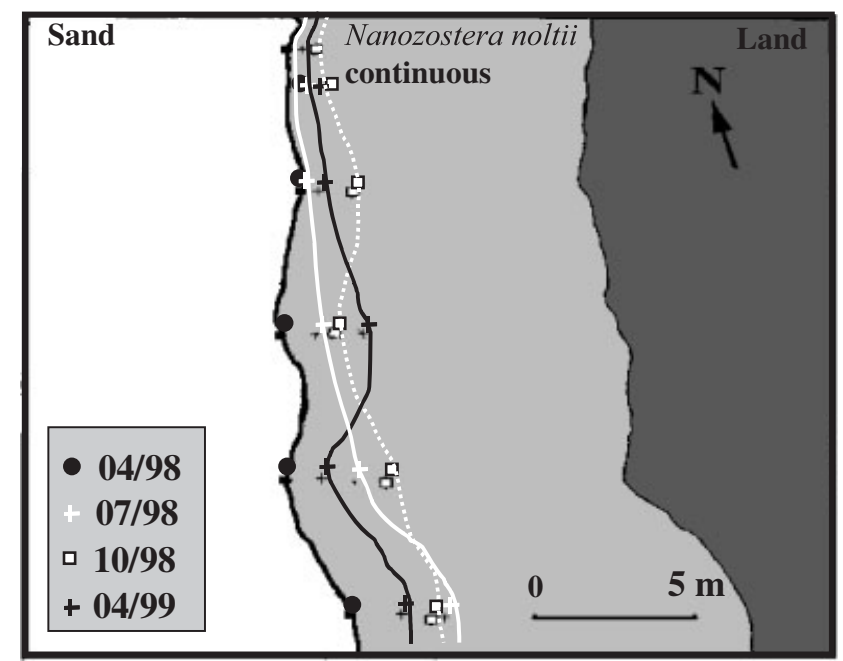

(a)

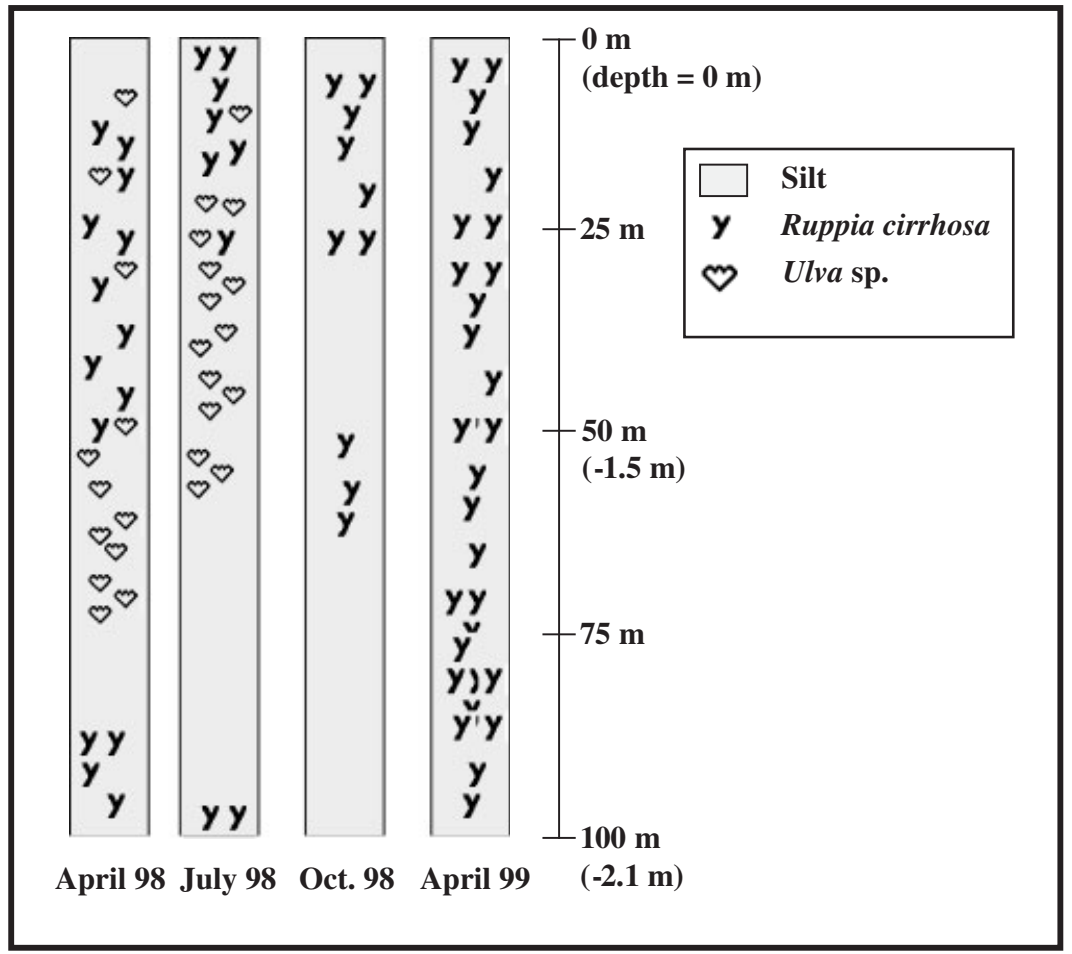

(b)

Figure 2. Record of monitoring structures in the Biguglia lagoon, from April 1998 to April 1999. (a) marked survey area; (b) transect.

per $\mathrm{m}^{2}$ for R. cirrhosa (at Biguglia; Kruskal-Wallis test, $t=19.4, p<0.05$ ), from 1358 to 21902 shoots per $\mathrm{m}^{2}$ for N. noltii (at Biguglia; Kruskal-Wallis test, $t=28.3, p<0.01$ ) and from 509 to 1471 shoots per $\mathrm{m}^{2}$ for C. nodosa (at Urbino; Kruskal-Wallis test, $t=16.9, p<0.05$; Table 2). However, it should be noted that the 


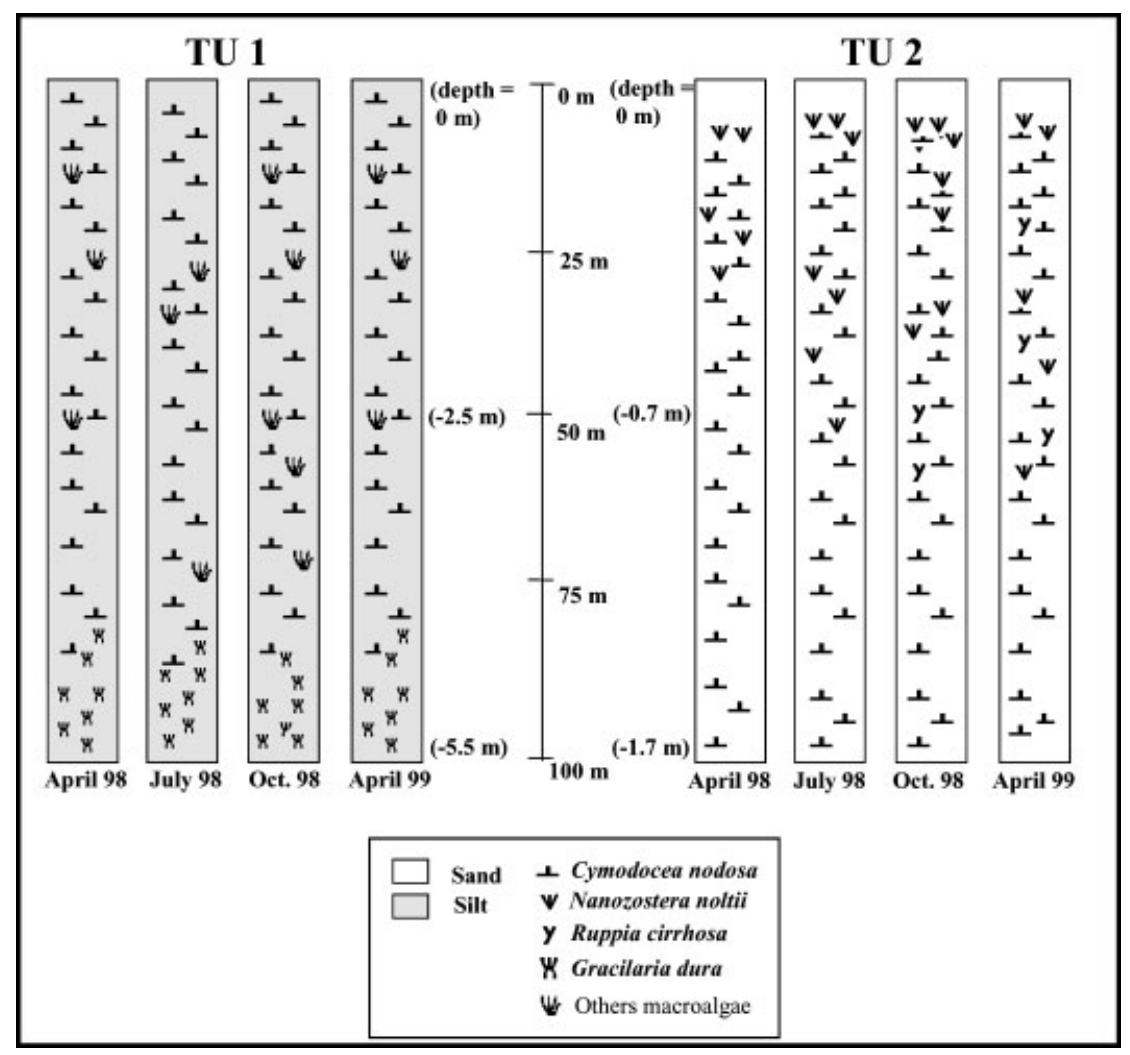

Figure 3. Record of monitoring structures in the Urbino lagoon, April 1998 to April 1999 (TU1, Transect 1; TU2, Transect 2).

density of $N$. noltii showed significant differences between the two lagoons, at least during certain periods of the year, with higher values at Biguglia (Mann-Witney tests, $p<0.05$ ).

For $C$. nodosa and $N$. noltii, the below-ground fraction was dominant in relation to the above-ground fraction, whereas the opposite was true for R. cirrhosa (Figure 4). The ratio of below-ground biomass/ above-ground biomass was high, both in C. nodosa (4.2) and in N. noltii (from 1.8 at Biguglia to 3.4 at Urbino). The below-ground biomass was higher in $R$. cirrhosa and $C$. nodosa than in $N$. noltii, regardless of the site considered (Kruskal-Wallis tests, $p<0.05$; Figure 4). For the above-ground biomass, the differences between species, for both sites taken together, are significant, with the lowest values recorded for $R$. cirrhosa, and the highest for C. nodosa (tests Kruskal-Wallis, $p<0.05$; Figure 4).

Phenological parameters were only considered for $C$. nodosa and $N$. noltii. The mean number of leaves per shoot varied little and the differences observed in the length and width of leaves were linked to the species under consideration, giving rise to a significantly different LAI (Table 2). Coefficient A is distinctly higher for $C$. nodosa $(53 \%)$ ) than for $N$. noltii $(24 \%)$. However, for $N$. noltii, there are significant differences in the total number of leaves, the width of adult leaves and the length of leaves, according to the site, but the LAI does not differ (Table 2; test Mann-Witney; $p<0.05$ ).

In order to initiate a short-term survey, the 1998 data were compared with those from 1999. A decrease in the length and width of leaves was apparent between 1998 and 1999, at both sites and for both C. nodosa and N. noltii (test Mann-Witney, $p<0.05$; Table 3). The shoot density was significantly lower in 1999 for $N$. noltii and R. cirrhosa whereas it was significantly higher for C. nodosa (Mann-Witney tests, $p<0.05$ ). In 
Table 2. Density and phenological data for different species of aquatic angiosperms during the year 1998 at the two sites studied $( \pm$ confidence interval $95 \%)$

\begin{tabular}{|c|c|c|c|c|}
\hline & \multicolumn{2}{|l|}{ Urbino lagoon } & \multicolumn{2}{|l|}{ Biguglia lagoon } \\
\hline & C. nodosa & N. noltii & N. noltii & R. cirrhosa \\
\hline \multirow{3}{*}{$\begin{array}{l}\text { Density per } \mathrm{m}^{2} \text { (mean) } \\
\text { minimum } \\
\text { maximum }\end{array}$} & $939.5 \pm 110.5$ & $7456.1 \pm 1903.2$ & $8849.4 \pm 3219.4$ & $6457.3 \pm 1598.9$ \\
\hline & 509.3 & 1924.2 & 1358.2 & 679.1 \\
\hline & 1471.4 & 15959.3 & 21901.5 & 12903.2 \\
\hline \multirow{3}{*}{$\begin{array}{l}\text { Number of leaves (mean) } \\
\text { minimum } \\
\text { maximum }\end{array}$} & $3.9 \pm 0.1$ & $3.6 \pm 0.1$ & $3.5 \pm 0.1$ & \\
\hline & 2.0 & 2.0 & 2.0 & \\
\hline & 6.0 & 5.0 & 5.0 & \\
\hline \multirow{3}{*}{$\begin{array}{l}\text { Length of adult leaves in mm (mean) } \\
\text { minimum } \\
\text { maximum }\end{array}$} & $145.6 \pm 8.6$ & $147.6 \pm 4.5$ & $168.7 \pm 6.0$ & \\
\hline & 24.0 & 20.0 & 16.0 & \\
\hline & 724.0 & 375.0 & 436.0 & \\
\hline \multirow{3}{*}{$\begin{array}{l}\text { Length of intermediate leaves in } \mathrm{mm} \text { (mean) } \\
\text { minimum } \\
\text { maximum }\end{array}$} & $80.7 \pm 7.8$ & $71.4 \pm 4.7$ & $87.08 \pm 6.15$ & \\
\hline & 2.0 & 4.0 & 5.0 & \\
\hline & 371.0 & 317.0 & 352.0 & \\
\hline \multirow{3}{*}{$\begin{array}{l}\text { Width of adult leaves in mm (mean) } \\
\text { minimum } \\
\text { maximum }\end{array}$} & $3.0 \pm 0.1$ & $1.3 \pm 0.0$ & $1.1 \pm 0.0$ & \\
\hline & 1.0 & $0.5^{-}$ & $0.5^{-}$ & \\
\hline & 5.5 & 15.0 & 2.0 & \\
\hline \multirow{3}{*}{$\begin{array}{l}\text { Width of intermediate leaves in mm (mean) } \\
\text { minimum } \\
\text { maximum }\end{array}$} & $2.4 \pm 0.1$ & $1.2 \pm 0.0$ & $1.1 \pm 0.0$ & \\
\hline & 1.0 & 0.5 & 0.5 & \\
\hline & 4.5 & 2.5 & 1.5 & \\
\hline \multirow{3}{*}{$\begin{array}{l}\text { Coefficient } \mathrm{A} \text { in } \% \text { (mean) } \\
\text { minimum } \\
\text { maximum }\end{array}$} & $52.5 \pm 3.0$ & $22.4 \pm 2.2$ & $25.4 \pm 2.5$ & \\
\hline & 0.0 & 0.0 & 0.0 & \\
\hline & 100.0 & 100.0 & 100.0 & \\
\hline \multirow{3}{*}{$\begin{array}{l}\mathrm{LAI} \text { in } \mathrm{m}^{2} \cdot \mathrm{m}^{-2} \text { (mean) } \\
\text { minimum } \\
\text { maximum }\end{array}$} & $1.3 \pm 0.4$ & $3.9 \pm 1.3$ & $4.0 \pm 0.4$ & \\
\hline & 0.9 & $1.2^{-.0 .0}$ & 1.1 & \\
\hline & 1.6 & 5.3 & 6.6 & \\
\hline
\end{tabular}

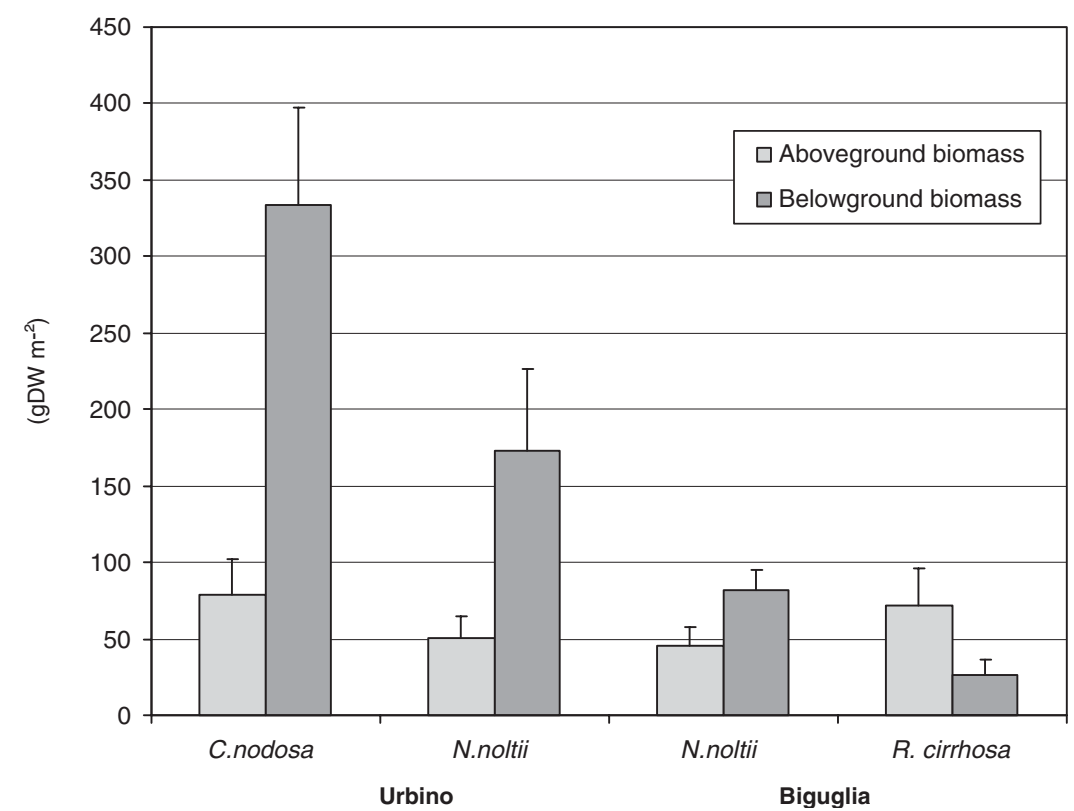

Figure 4. Biomass of different species of seagrasses, during 1998, at the two sites studied ( \pm confidence interval $95 \%$ ). 
Table 3. Density, biomass and phenological data for different species of aquatic angiosperms, for January, April and July 1998 and for January, April and July 1999, at the two sites studied ( \pm confidence interval $95 \%$ )

\begin{tabular}{|c|c|c|c|c|}
\hline & \multicolumn{2}{|l|}{ Urbino lagoon } & \multicolumn{2}{|l|}{ Biguglia lagoon } \\
\hline & C. nodosa & N. noltii & N. noltii & R. cirrhosa \\
\hline \multicolumn{5}{|c|}{ Density per $\mathrm{m}^{2}$ (mean) } \\
\hline 1998 & $871.5 \pm 127.5$ & $8485.2 \pm 2238.2$ & $10675.9 \pm 393.1$ & $7372.2 \pm 1795.6$ \\
\hline 1999 & $1512.9 \pm 447.0$ & $2392.3 \pm 493.1$ & $1705.3 \pm 371.8$ & $4255.8 \pm 986.6$ \\
\hline \multicolumn{5}{|c|}{ Above-ground biomass per g DW $\mathrm{m}^{-2}$ (mean) } \\
\hline 1998 & $85.7 \pm 29.9$ & $61.4 \pm 15.6$ & $56.1 \pm 12.4$ & $92.7 \pm 24.4$ \\
\hline 1999 & $69.5 \pm 33.2$ & $19.9 \pm 7.1$ & $23.1 \pm 8.4$ & $129.6 \pm 82.3$ \\
\hline \multicolumn{5}{|c|}{ Below-ground biomass per $\mathrm{g} \mathrm{DW} \mathrm{m} \mathrm{D}^{-2}$ (mean) } \\
\hline 1998 & $286.2 \pm 68.6$ & $185.5 \pm 63.6$ & $79.2 \pm 15.8$ & $33.1 \pm 12.4$ \\
\hline 1999 & $436.0 \pm 132.5$ & $243.2 \pm 92.3$ & $48.9 \pm 15.0$ & $30.1 \pm 9.7$ \\
\hline \multicolumn{5}{|c|}{ Number of leaves (mean) } \\
\hline 1998 & $4.0 \pm 0.1$ & $3.7 \pm 0.1$ & $3.6 \pm 0.1$ & \\
\hline 1999 & $4.0 \pm 0.1$ & $3.4 \pm 0.1$ & $3.5 \pm 0.1$ & \\
\hline \multicolumn{5}{|c|}{ Length of adult leaves in mm (mean) } \\
\hline 1998 & $153.5 \pm 11.0$ & $160.8 \pm 5.1$ & $185.4 \pm 6.7$ & \\
\hline 1999 & $133.6 \pm 11.4$ & $85.7 \pm 3.4$ & $118.0 \pm 5.1$ & \\
\hline \multicolumn{5}{|c|}{ Length of intermediate leaves in mm (mean) } \\
\hline 1998 & $94.5 \pm 10.4$ & $78.3 \pm 5.6$ & $95.9 \pm 7.4$ & \\
\hline 1999 & $75.0 \pm 9.7$ & $41.5 \pm 3.2$ & $78.9 \pm 6.3$ & \\
\hline \multicolumn{5}{|c|}{ Width of adult leaves in mm (mean) } \\
\hline 1998 & $2.9 \pm 0.1$ & $1.4 \pm 0.0$ & $1.1 \pm 0.0$ & \\
\hline 1999 & $3.3 \pm 0.1$ & $1.2 \pm 0.0$ & $1.2 \pm 0.0$ & \\
\hline \multicolumn{5}{|c|}{ Width of intermediate leaves in mm (mean) } \\
\hline 1998 & $2.4 \pm 0.1$ & $1.3 \pm 0.0$ & $1.1 \pm 0.0$ & \\
\hline 1999 & $2.5 \pm 0.1$ & $1.1 \pm 0.0$ & $1.1 \pm 0.0$ & \\
\hline \multicolumn{5}{|c|}{ Coefficient $\mathrm{A}$ in $\%$ (mean) } \\
\hline 1998 & $50.8 \pm 3.6$ & $22.5 \pm 2.5$ & $26.2 \pm 2.8$ & \\
\hline \multirow{2}{*}{\multicolumn{5}{|c|}{ LAI in $\mathrm{m}^{2} \cdot \mathrm{m}^{-2}$ (mean) }} \\
\hline & & & & \\
\hline 1998 & $1.3 \pm 0.5$ & $4.8 \pm 1.5$ & $5.0 \pm 1.2$ & \\
\hline 1999 & $1.6 \pm 0.5$ & $0.7 \pm 0.2$ & $0.7 \pm 0.4$ & \\
\hline
\end{tabular}

addition, with $N$. noltii, there was a significant decrease in the above-ground biomass, in the total number of leaves and thus in LAI, at both Urbino and Biguglia. On the other hand, Coefficient A showed a significant increase both for $N$. noltii (at both sites) and for C. nodosa (Mann-Witney tests, $p<0.05$ ).

\section{General distribution pattern}

The mapping of the distribution, based on computer processing of aerial photographs, resulted in the identification of the main meadows and bottom types: silt, sand, aquatic angiosperms and macroalgae for the Biguglia lagoon (Figure 5), and silt, sand, aquatic angiosperms and pebbly bottom for the Urbino lagoon (Figure 6). Analysis of the map of the Biguglia lagoon revealed a predominance of silty bottoms $(77.0 \%$ of total area), especially in the highly turbid central areas and in the south of the lagoon, and relatively small areas of aquatic angiosperms (13\% of total area; Figure 5). These aquatic angiosperms were $95 \% R$. cirrhosa meadows, $P$. pectinatus only occurring in the south-west part of the lagoon. There were large formations of macroalgae $(6.5 \%$ of total area), which took the form of tufts within the $R$. cirrhosa meadows. Posidonia oceanica (L.) Delile, an exclusively marine species, was only found in the form of 


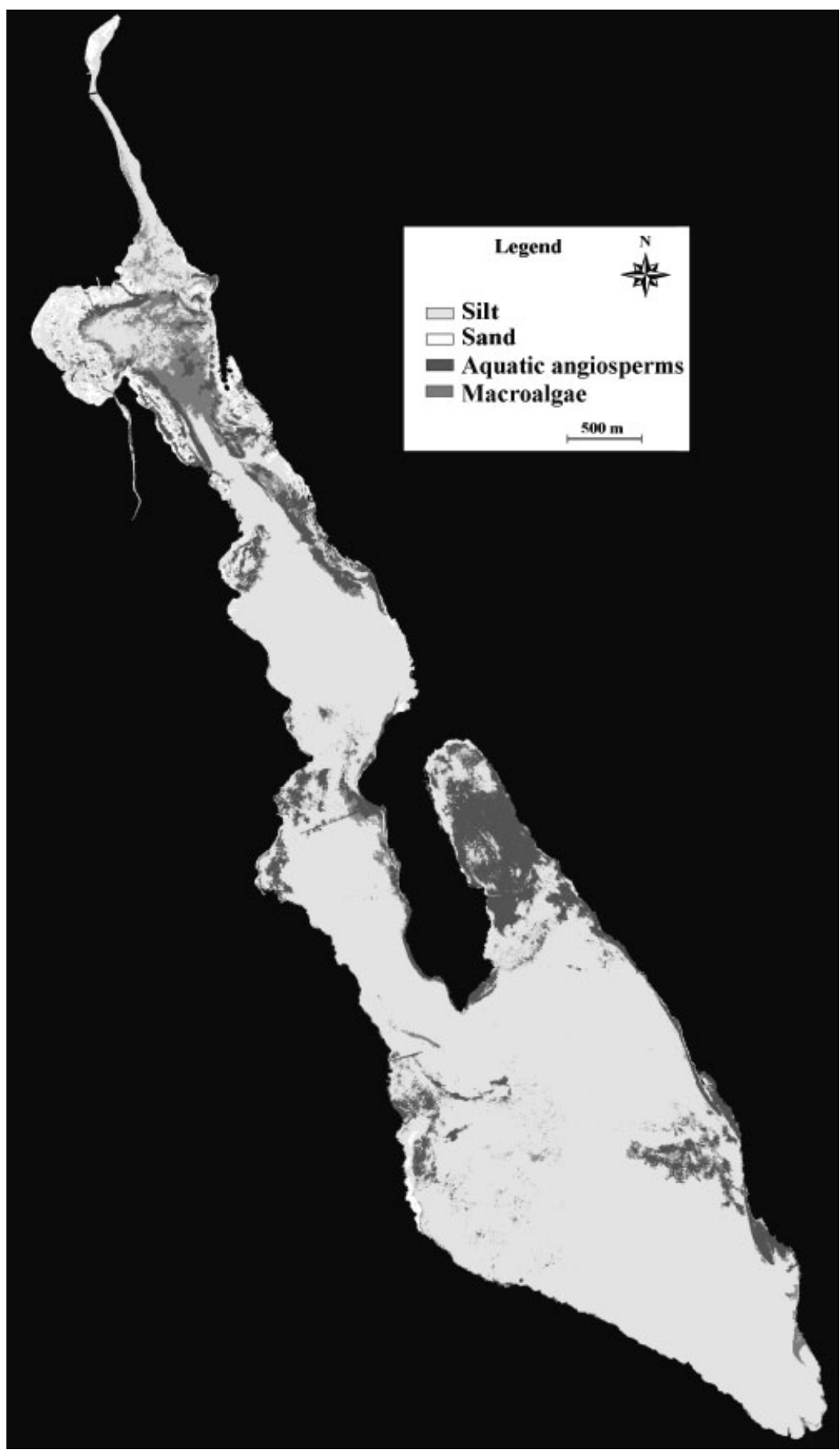

Figure 5. Localization of meadows and bottom types in the Biguglia lagoon. 


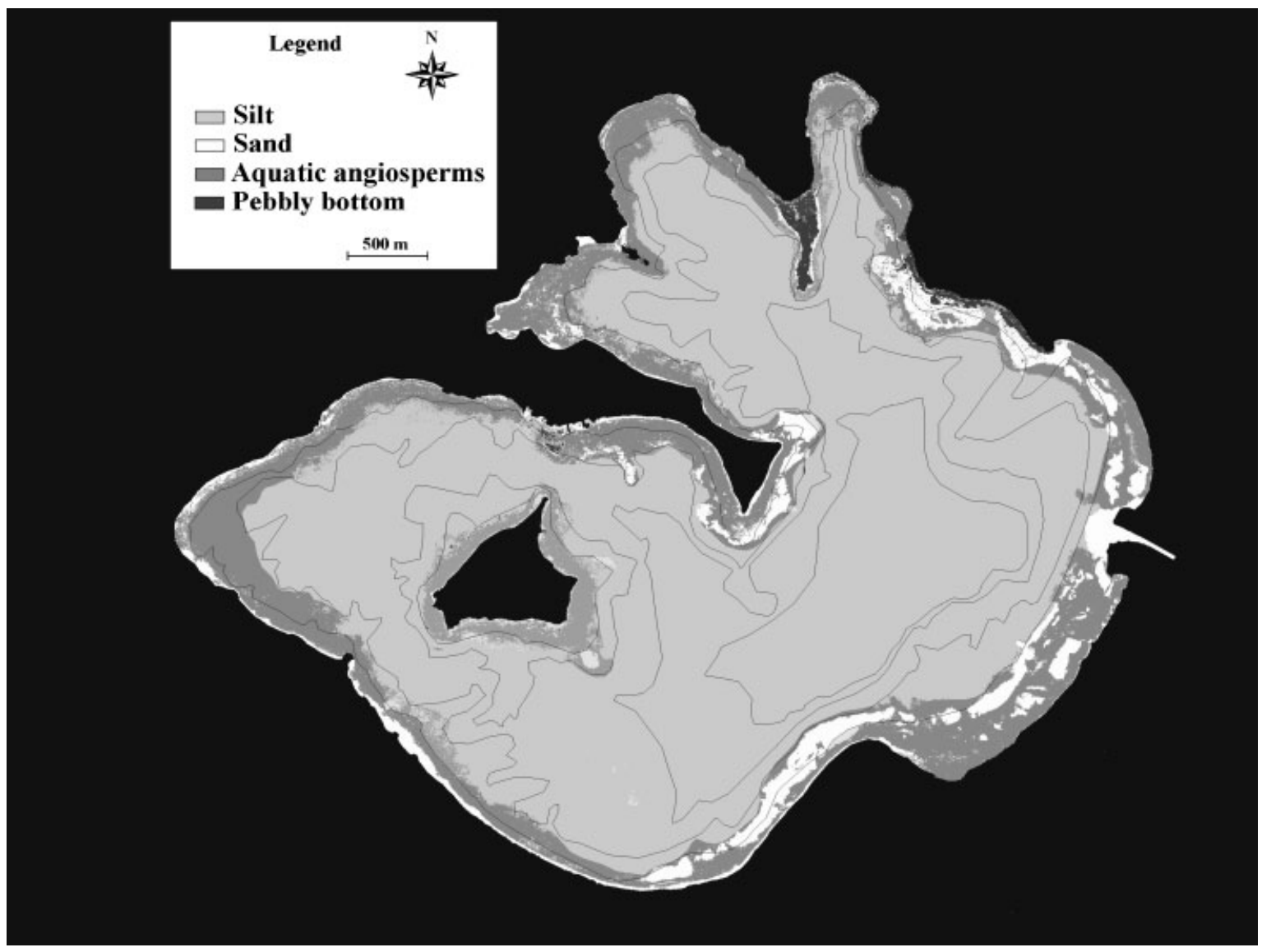

Figure 6. Localization of meadows and bottom types in the Urbino lagoon.

stranded litter, in the northern part, partly blocking the connecting channel. At the Urbino lagoon (Figure 6 ), silt predominated $(70.0 \%$ of total area) and occupied the central part of the lagoon. The aquatic angiosperms formed a continuous belt around the outer rim of the lagoon (20.7\% of total area) from the surface to $-5 \mathrm{~m}$. They were almost exclusively $C$. nodosa meadows $(96 \%)$. The sand was also localized around the outer rim of the lagoon ( $7.5 \%$ of total area), whereas the pebbly bottom occupied only very small areas in the north of the lagoon.

\section{DISCUSSION AND CONCLUSIONS}

The mapping of the distribution of the plant communities and bottom types confirms the differences already reported between the two lagoons (Pergent-Martini et al., 1997). Although silty substrates are well represented at both sites, there is a predominance of aquatic angiosperms (by percentage) at the Urbino lagoon. The distribution pattern within each lagoon varies, with the aquatic angiosperms restricted to the outer rim of the lagoon at Urbino (Figure 6) but scattered over virtually the whole area of the lagoon at Biguglia (Figure 5). In addition, the species differ, with a strong predominance of marine species at Urbino (e.g. C. nodosa and N.noltii) and species with freshwater affinities at Biguglia (e.g. R. cirrhosa, R. maritime, 
$P$. pectinatus). Salinity is an important environmental factor that can affect the distribution of aquatic angiosperms. The distribution of $N$. noltii is restricted to the area around the channel at Biguglia, reflecting the salinity profile, in the lagoon showing a decreasing salinity gradient from the north to the south with an amplitude of 5 to 10. The north basin is under marine influence (high salinity) and the south basin is under freshwater influence (low salinity) (Orsoni et al., 2001). On the other hand, N. noltii is more widely distributed throughout Urbino lagoon which has a homogeneous salinity throughout the water mass with values close to open-sea salinities (Orsoni et al., 2001).

The higher nutrient levels in Biguglia (ammonium: 0.66 to $53.77 \mu \mathrm{M}$ in Biguglia, 0.14 to $3.80 \mu \mathrm{M}$ in Urbino; nitrites: 0.12 to $6.17 \mu \mathrm{M}$ in Biguglia, 0.09 to $0.74 \mu \mathrm{M}$ in Urbino; nitrates: 0.01 to $17.25 \mu \mathrm{M}$ in Biguglia, 0.06 to $1.00 \mu \mathrm{M}$ in Urbino) could cause indirect negative effects on the seagrasses, with the proliferation of macroalgal blooms (Sfriso et al., 2003), Lemna sp. (personal observations) or phytoplankton. It is likely that the development of macroalgae or Lemna sp., or phytoplankton in the Biguglia lagoon resulted in a decline in the intensity of the light (by decreasing light by their shade or by increasing turbidity) reaching the seagrasses. Laugier et al. (1999) report that in the presence of macroalgae, Zostera increases leaf height in order to reduce the shading effect and that the number of leaves per shoot is positively correlated with light. To the extent that the length of leaves of $N$. noltii is significantly greater at Biguglia, and that the total number of leaves per shoot is lower, it would appear that this lagoon has more turbid waters, consistent with measurements reported by Orsoni et al. (2001) of between 0.9 and 11.8 NTU in Biguglia, compared with between 0.6 and 1.9 NTU in Urbino.

Temperature is an important environmental factor that can affect the morphology of seagrasses. The cause of the increased development of the above-ground biomass of $N$. noltii at Urbino is probably related to the higher temperature of this lagoon, similar to the Thau lagoon (Laugier et al., 1999). In fact, the temperature data oscillate between 9.8 and $27.9^{\circ} \mathrm{C}$ in Biguglia and between 8.8 and $28.3^{\circ} \mathrm{C}$ in Urbino (Orsoni et al., 2001).

It would appear that grazing levels differ between the two lagoons. Although it does not differ significantly throughout the year, coefficient A, for $N$. noltii, is higher at Biguglia. Several authors report an increase in the growth of the leaves of aquatic plants when they are exposed to heavy grazing (Cebrian et al., 1996, 1998; Cebrian and Duarte, 1998). The Biguglia lagoon is a major haven for birds (Cemagref, 1982), for which N. noltii is the favoured food (Tamisier and Boudouresque, 1994). In contrast, at Urbino, the sea urchin Paracentrotus lividus is the major consumer of seagrasses and it is particularly abundant in C. nodosa beds (Fernandez et al., 2001) which is a favourite food (Traer, 1980), as confirmed by the significantly higher coefficient A rate at Urbino for this species $(53 \%)$.

An estimate of the mean annual biomass (above-ground + below-ground) of the aquatic plants may be calculated, on the basis of the surface area occupied by the meadows in each lagoon. Assuming that the Biguglia meadows are exclusively made up of $R$. cirrhosa, the biomass values range from $23 \mathrm{t}$ (DW; October 1998) to $735 \mathrm{t}$ (DW; July 1999), or an annual mean of $230 \mathrm{t}$ (DW). The same calculation, at Urbino, on the basis of meadows made up of $95 \%$ C. nodosa and $5 \% \mathrm{~N}$. noltii, gives a biomass that ranges from $244 \mathrm{t}$ (DW; April 1999) to $1062 \mathrm{t}$ (DW; July 1999), or an annual mean of $732 \mathrm{t}$ (DW), which represents a biomass that is three times greater. Integrating the $\mathrm{P} / \mathrm{B}$ ratio for each species, on the basis of data from the literature (Table 4), gives an estimation of the primary production for each lagoon. This ranges from 86 to $469 \mathrm{~g} \mathrm{C} \mathrm{m}^{-2} \mathrm{yr}^{-1}$ at Biguglia, and from 190 to $1301 \mathrm{~g} \mathrm{C} \mathrm{m}^{-2} \mathrm{yr}^{-1}$ at Urbino (depending on whether the $\mathrm{P} / \mathrm{B}$ ratio is minimum or maximum for the species considered; Table 5). The availability of data on the primary production of $C$. nodosa for the Urbino lagoon (Agostini, 2001; Agostini et al., 2003b) enables this estimation to be refined, with a production rate ranging from 1267 to $1301 \mathrm{~g} \mathrm{C} \mathrm{m}^{-2} \mathrm{yr}^{-1}$. Primary production is thus distinctly higher at Urbino than at Biguglia. The estimated values are comparable, for the Biguglia lagoon, to the production rate of coral reefs (Crossland et al., 1991 (in Duarte and Chiscano, 1999)) or macroalgae (Charpy-Roubaud and Sournia, 1990 (in Duarte and Chiscano, 1999)) whereas, for 
Table 4. Bibliographical data for biomass (below-ground + above-ground), net primary production and production/biomass ratio for the different species studied, in lagoonal environments

\begin{tabular}{|c|c|c|c|c|}
\hline Site & $\begin{array}{l}\text { Biomass } \\
\left(\mathrm{g} \mathrm{DW} \mathrm{m}^{-2}\right)\end{array}$ & $\begin{array}{l}\text { Production } \\
\left(\mathrm{g} \mathrm{C} \mathrm{m}^{2} \mathrm{yr}^{-1}\right)\end{array}$ & $\begin{array}{l}\text { Ratio } \\
\text { production/ } \\
\text { biomass }\end{array}$ & Reference \\
\hline \multicolumn{5}{|l|}{ C. nodosa } \\
\hline Mar Menor - Spain & $68-220$ & $206-505$ & $2.3-3.0$ & Terrados and Ros, 1992 \\
\hline Venice lagoon - Italy & $399-1841$ & 826 & $0.5-2.1$ & Rismondo et al., 1997 \\
\hline Urbino lagoon - France & 777 (mean) & 2470 & 3.2 & Agostini, 2001/Agostini et al., 2003b \\
\hline \multicolumn{5}{|l|}{ N. noltii } \\
\hline Thau lagoon - France & 44-437 & 539 & $1.2-12.3$ & Laugier, 1998 \\
\hline Thau lagoon - France & $45.8-95$ & 197 & $0.2-4.3$ & Plus et al., 2001 \\
\hline \multicolumn{5}{|l|}{ R. cirrhosa } \\
\hline Camargues - France & $50-160$ & $59-141$ & $0.9-1.2$ & Verhoeven, 1980 \\
\hline Santo André lagoon — Portugal & $72-388$ & 135 & $0.4-1.9$ & Calado and Duarte, 2000 \\
\hline Valle Smarlacca lagoon — Italy & 150 & 594 & 4.0 & Azzoni et al., 2001 \\
\hline Ebro Delta - Spain & $75-672$ & 361 & $0.5-4.8$ & Menéndez, 2002 \\
\hline
\end{tabular}

the Urbino lagoon, they are of the same order as that of temperate forests (Whittaker, 1975 (in Duarte and Chiscano, 1999)) or marsh plants (Woodwell et al., 1973 (in Duarte and Chiscano, 1999)).

The full set of investigations carried out for this reference state survey show that while, a priori, the two lagoons are similar in structure (aquatic angiosperm-based ecosystems), they present functional differences, specifically linked to environmental conditions.

Comparing the biological parameters obtained from the Corsican lagoons with those recorded for the same species in other Mediterranean lagoons, it is apparent that the values are similar (Table 5). At the most, it may be noted that the values for the total biomass of $R$. cirrhosa at Biguglia are low, but close to those obtained in the Camargue natural reserve (Verhoeven, 1980). Similarly, the values for the aboveground biomass of $N$. noltii at the two sites studied are minimal in comparison with the data available for lagoons where there is greater human pressure (Table 5). The same is true for C. nodosa, for which the density values at Urbino are lower than those recorded in the Venice lagoon (Rismondo et al., 1997; Sfriso and Ghetti, 1998). Although it is difficult solely on the basis of these observations to establish a comparative state of the Corsican lagoons, it would appear that, while human pressure does exist (Table 1), it cannot be compared with that occurring at other lagoons. The impact of human activities on the Corsican lagoons does not appear to alter the development of aquatic plants to a marked degree, whereas this is already the case for other lagoons that are exposed to greater human pressure, such as the Thau and Venice lagoons.

The observations carried out in the course of the monitoring and temporal survey of the Corsican lagoons show that considerable changes occurred between 1998 and 1999, both on the transects and with regard to the biological parameters.

The variations recorded at the Biguglia marked survey area are mainly linked to variations in abiotic parameters. Orsoni et al. (2001) show an increase in rainfall and turbidity from December 1998 to February 1999 , which seems to be the cause of the regression in population of $N$. noltii, a species with marine affinities that is particularly sensitive to marked decreases in salinity and has poor tolerance of high turbidity (Riouall, 1972). Orsoni et al. (2001) also report strong increases in nitrite and nitrate content from November 1998 to May 1999, which would appear to correspond to the general disappearance of the $R$. cirrhosa meadows. This nutrient enrichment is likely to favour the development of macroalgae, to the detriment of aquatic angiosperms (Hartog Den, 1994; Coffaro and Bocci, 1997). So, the development of 


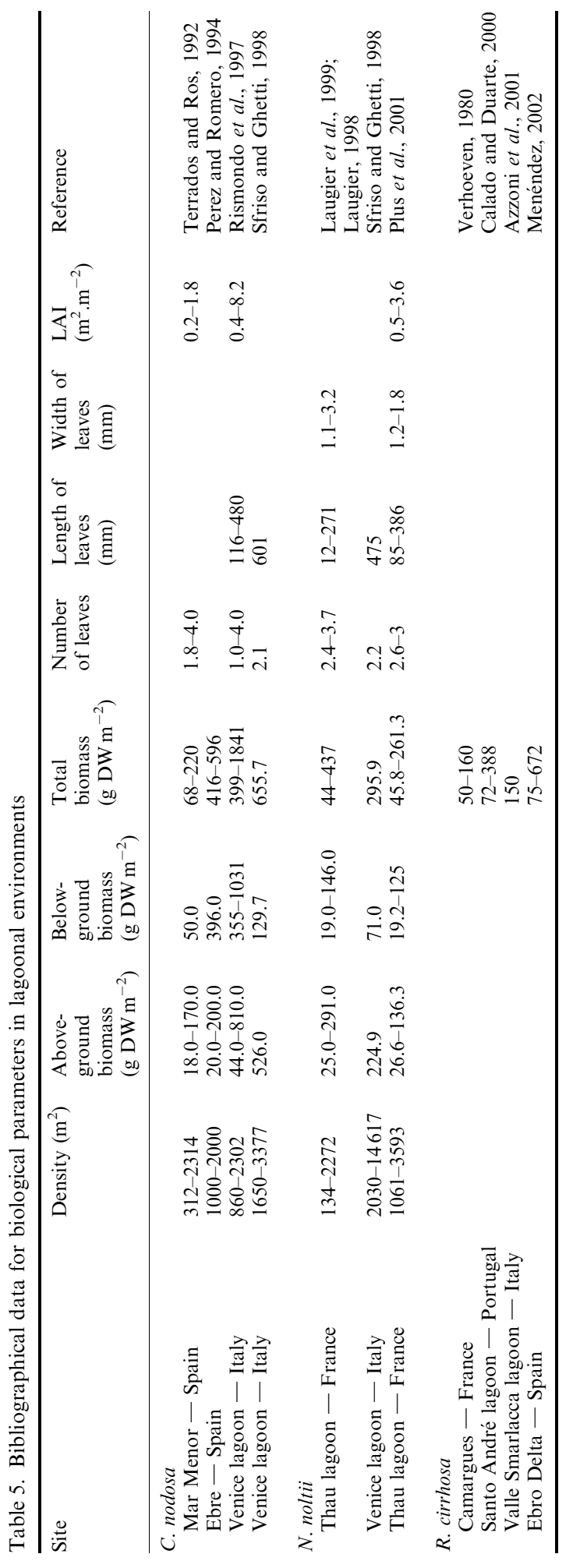


Ulva sp. was observed along the transect at Biguglia, which has already been reported both for Biguglia (De Casabianca, 1979) and for other coastal lagoons (Coffaro and Bocci, 1997; De Casabianca et al., 1997). Furthermore, the increase in these macroalgae, and their subsequent decomposition, results in the occurrence of anoxic conditions that may be responsible of degradation of the seagrasses (Hartog Den, 1994). Generally speaking, the decline in the biological parameters observed would appear to reflect a change in environmental conditions between 1998 and 1999. At the Urbino lagoon, alterations in the plant communities would appear to be more limited, but show the same trend towards a reduction in the biological parameters. It would thus appear that the explanation for this putative degradation in environmental conditions must be sought on a regional scale (e.g. unusually high runoff from catchment areas, climate change) rather than at the level of one of the lagoons. Significant inter-annual variations were observed for many biological parameters. These observations confirm the speed of inter-annual evolution in the lagoons as a function of changing environmental conditions (Kjerfve, 2000). While human responsibility cannot be ruled out, nor can it be the direct cause of these alterations. The greater range in the degradation of the biological parameters recorded at Biguglia (e.g. reduction in density by a factor of 1 to 20$)$ must be due, in part at least, to the difference in the size of the catchment areas $\left(180 \mathrm{~km}^{2}\right.$ for the Biguglia lagoon compared to $30 \mathrm{~km}^{2}$ for the Urbino lagoon) and the more variable environmental characteristics. Furthermore, the lower depth range of this lagoon prevents it from absorbing these environmental fluctuations, as is certainly the case at Urbino.

The observations made in the course of the development of the monitoring survey of vegetation in the Corsican lagoons show the strong influence of abiotic conditions on the distribution patterns of the aquatic plants in semi-open environments, as well as the high productivity rate in these environments. While the existence of human activities (Table 1) can alter the way these lagoons function, it would appear for the time being that they only do so to a limited extent. Nevertheless, the evidence for alteration of environmental parameters at a regional level confirms the relevance of this monitoring survey with a view to providing an early warning of disturbances engendered by human activities. The methods adopted, whether it is the monitoring of the fixed marks, the permanent transects, the study of the morphological parameters and/or the use of the image processing of aerial photographs are all relevant in the implementation of a monitoring system. This work confirms the importance of more intensive and reliable surveillance of aquatic angiosperm meadows in the conservation and long-term management of coastal lagoons. Such long-term management has to (i) characterize potential sources of disturbances present in the catchment area and develop purification networks; (ii) manage openings to the sea, to maintain the exchanges of water between the marine and lagoonal environment; and (iii) manage the activities bringing out organic matters in the lagoonal environment (fish farming); with the aim of limiting concentrations in fatal nutriments to seagrasses, these species being characteristic of a good quality of the environment.

\section{ACKNOWLEDGEMENTS}

This work was carried out and funded under the Programme National d'Océanologie Côtiére (Pnoc) in partnership with IFREMER and the French Ministére de l'Environnement (Environment Ministry), for the valorization of Mediterranean lagoons. Some of the results were acquired from the European Life and Interreg II programmes. The authors would like to thank O. Dumay and C. Segui for their participation in field missions and A. Lindsey-Clark for help with the English translation.

\section{REFERENCES}

Agenc. 1989. Etang de Biguglia, Haute Corse. Dossier scientifique, Propositions pour la création d'une réserve naturelle.

Rapport Agenc, Iare, Srae et Club Ornithologique Association des amis du Parc Naturel Régional de Corse, France. 
Agostini S. 2001. Contribution á l'étude des herbiers á phanérogames dans les étangs de Corse. Thése doctorale, Université de Corse, France.

Agostini S, Marchand B, Pergent G. 2003a. Temporal and spatial changes of seagrass meadows in a mediterranean coastal lagoon. Oceanologica Acta 25: 297-302.

Agostini S, Pergent G, Marchand B. 2003b. Growth and primary production of Cymodocea nodosa in a coastal lagoon. Aquatic Botany 76: 185-193.

Azzoni R, Giordani G, Bartoli M, Welsh DT, Viaroli P. 2001. Iron, sulphur and phosphorus cycling in the rhizosphere sediments of a eutrophic Ruppia cirrhosa meadow (Valle Smarlacca, Italy). Journal of Sea Research 45: 15-26.

Bacher C, Bioteau H, Chapelle A. 1995. Modelling the impact of a cultivated oyster population on the nitrogen dynamics: the Thau lagoon case (France). Ophelia 42: 29-54.

Bettinetti A, Pypaert P, Sweerts JP. 1996. Application of an integrated management approach to the restoration project of the lagoon of Venice. Journal of Environmental Management 46(3): 207-227.

Blandin P. 1986. Bioindicateurs et diagnostic des systémes écologiques. Bulletin d'Ecologie 17(4): 211-307.

Boulmer M, Lorenzoni C, Cantera C. 1997. Plan de gestion de la réserve naturelle de Biguglia. Conseil Général de la Haute-Corse, France.

Calado G, Duarte P. 2000. Modelling growth of Ruppia cirrhosa. Aquatic Botany 68: 29-44.

Carasp. 1997. Les aires protégées de Méditerranée. De Genéve 1982 á Barcelone 1995. Carasp \& Unep / Ministére Environnement et Aménagement du Territoire de Tunisie.

Cebrian J, Duarte CM. 1998. Patterns in leaf herbivory on seagrasses. Aquatic Botany 60(1): 67-82.

Cebrian J, Duarte CM, Marbá N, Enriquez S, Gallegos M, Olesen B. 1996. Herbivory on Posidonia oceanica: magnitude and variability in the Spanish Mediterranean. Marine Ecology Progress Series 130(1-3): 147-155.

Cebrian J, Duarte CM, Agawin NSR, Merino M. 1998. Leaf growth response to simulated herbivory: a comparison among seagrass species. Journal of Experimental Marine Biology and Ecology 220(1): 67-81.

Cemagref, 1982. Les étangs corses, niveaux trophiques, critéres d'aménagement. Rapport Cemagref, Somivac \& Istpm/ Mission interministérielle pour la protection et l'aménagement de l'espace naturel méditerranéen.

Charpy-Roubaud C, Sournia A. 1990. The comparative estimation of phytoplanktonic and microphytobenthic production in the oceans. Marine Microbial Food Webs 4: 31-57.

Clanzig S. 1992. Impact des activités aquacoles sur le benthos de la lagune d'Urbino (Corse). C.I.E.L. 16, France.

Coeurd'acier P. 1987. Rapport d'activité sur les étangs de Diana et d'Urbino. Ifremer: Santa Maria di Poggio, France.

Coffaro G, Bocci M. 1997. Resources competition between Ulva rigida and Zostera marina: a quantitative approach applied to the Lagoon of Venice. Ecological Modelling 102(1): 81-95.

Crossland CJ, Hatcher BG, Smith SV. 1991. Role of coral reefs in global ocean production. Coral Reefs 10: 55-64.

De Casabianca ML. 1979. Dynamique pluriannuelle des macrophytes en milieu lagunaire. Commission internationale pour l'exploration scientifique de la mer méditerranée 25/26(3): 175-176.

De Casabianca ML, Posada F. 1998. Effect of environmental parameters on the growth of Ulva rigida (Thau lagoon, France). Botanica Marina 41(2): 157-165.

De Casabianca ML, Laugier T, Collart D. 1997. Impact of shellfish farming eutrophication on benthic macrophyte communities in the Thau lagoon, France. Aquaculture International 5: 301-314.

Deslous-Paoli JM, Souchu P, Mazouni N, Juge C, Dagault F. 1998. Relationship between environment and resources: impact of shellfish farming on a Mediterranean lagoon (Thau, France). Oceanologica Acta 21(6): 831-843.

Duarte CM, Chiscano CL. 1999. Seagrass biomass and production: a reassessment. Aquatic Botany 65: 159-174.

Duarte CM, Martinez R, Barron C. 2002. Biomass, production and rhizome growth near the northern limit of seagrass (Zostera marina) distribution. Aquatic Botany 72: 183-189.

Fernandez C, Caltagirone A, Johnson M. 2001. Demographic structure suggests migration of the sea urchin Paracentrotus lividus in a coastal lagoon. Journal of the Marine Biological Association UK 80: 3713-3715.

Frisoni GF, Dutrieux E. 1992. L'étang de Biguglia - Diagnostic écologique 1991-1992. Rapport Iare, France.

Giraud G. 1977. Essai de classement des herbiers de Posidonia oceanica (Linné) Delile. Botanica Marina 20(8): 487-491.

Guilizzoni P. 1991. The role of heavy metals and toxic materials in the physiological ecology of submersed macrophytes. Aquatic Botany 41: 87-109.

Hartog Den C. 1994. Suffocation of a littoral Zostera bed by Enteromorpha radiata. Aquatic Botany 47: 21-28.

Herrera-Silveira JA. 1996. Salinity and nutrients in a tropical coastal lagoon with groundwater discharges to the Gulf of Mexico. Hydrobiologia 321(2): 165-176.

Kjerfve B. 2000. Coastal Lagoon Processes. Elsevier Oceanography Series: Amsterdam.

Laugier T. 1998. Ecologie de deux phanérogames marines sympatriques - Zostera marina L. et Z. noltii Hornem. — dans l'étang de Thau (Hérault, France). Thése doctorale, Université Montpellier II; 142 pp. + Ann.

Laugier T, Rigollet V, De Casabianca ML. 1999. Seasonal dynamics in mixed eelgrass beds, Zostera marina L. and Z. noltii Hornem., in a Mediterranean coastal lagoon (Thau lagoon, France). Aquatic Botany 63: 51-69. 
Longere P, Dorel D, Marin J. 1972. Etude bathymétrique et sédimentologique des étangs de Diane et d'Urbino en Corse. Revue des travaux de l'Institut des Pêches maritimes 36(1): 31-45.

Marzano CN, Liaci LS, Fianchini A, Gravina F, Mercurio M, Corriero G. 2003. Distribution, persistence and change in the macrobenthos of the lagoon of Lesina (Apulia, southern Adriatic Sea). Oceanologica Acta 26: $57-66$.

Menéndez M. 2002. Net production of Ruppia cirrhosa in Ebro Delta. Aquatic Botany 73(2): 1-7.

Meriaux JL, Wattez JR. 1980. Les végétations aquatiques et subaquatiques. Relations avec la qualité des eaux. In La Pollution des Eaux Continentales. Incidence sur les Biocénoses Aquatiques, Pesson P (ed.). Gauthier-Villars: Paris; 225-242.

Millet B, Guelorget O. 1993. Relationships between benthic communities and physical environment in a lagoon ecosystem. Journal of Coastal Research 9(2): 378-389.

Montague CL, Ley JA. 1993. A possible effect of salinity fluctuation on abundance of benthic vegetation and associated fauna in northeastern Florida bay. Estuaries 16(4): 703-717.

Orsoni V, Souchu P, Sauzade D. 2001. Caractérisation de l'état d'eutrophisation des trois principaux étangs corses (Biguglia, Diana et Urbino), et proposition de renforcement et leur surveillance. Rapport Ifremer, France.

Pasqualini V, Pergent-Martini C, Fernandez C, Pergent G. 1997. The use of airborne remote sensing for benthic cartography: advantages and reliability. International Journal of Remote Sensing 18(5): 1167-1177.

Pearce F, Crivelli AJ. 1994. Caractéristiques générales des zones humides méditerranéennes. Conservation des zones humides méditerranéennes, Programme MedWet, Fondation Tour du Valat publish., Arles, France.

Perez M, Romero J. 1994. Growth dynamics, production, and nutrient status of the seagrass Cymodocea nodosa in a Mediterranean semi-estuarine environment. Marine Ecology, PSZNI 15(1): 51-64

Pergent G, Ben Maïz N. 2001. Le lac Nord de Tunis: exemple de restauration d'une lagune méditerranéenne. In Restauration des Écosystémes Côtiers, Ifremer (ed.). Colloque 8 et 9 Nov. 2000, Brest, France; 168-178.

Pergent-Martini C, Fernandez C, Agostini S, Pergent G. 1997. Les étangs de Corse, bibliographie - Synthése 1997. Contrat Equipe Ecosystémes Littoraux - Université de Corse/Office de l'Environnement de la Corse \& Ifremer, France.

Plus M, Deslous-Paoli JM, Auby I, Dagault F. 2001. Factors influencing primary production of seagrass beds (Zostera noltii Hormen.) in the Thau lagoon (French Mediterranean coast). Journal of Experimental Marine Biology and Ecology 259: 63-84.

Ramade F. 1990. Conservation des Ecosystémes méditerranéens - Enjeux et Perspectives. Les Fascicules du Plan Bleu, Pnue/Pam Press: France.

Riouall R. 1972. Contribution á l'étude de la flore des étangs de Berre et de Vaïne (Bouches-du-Rhône). Thése de 3éme cycle, Université Aix-Marseille II, France.

Rismondo A, Curiel D, Marzocchi M, Scattolin M. 1997. Seasonal pattern of Cymodocea nodosa biomass and production in the lagoon of Venice. Aquatic Botany 58(1): 55-64.

Sacchi C. 1985. Le sel de La Palice: réflexion sur le paralin méditerranéen. Memoria Biologia marina e di Oceanografia 15: 71-89.

Sfriso A, Ghetti PF. 1998. Seasonal variation in biomass, morphometric parameters and production of seagrasses in the lagoon of Venice. Aquatic Botany 61(3): 207-223.

Sfriso A, Birkemeyer T, Ghetti PF. 2001. Benthic macrofauna changes in areas of Venice lagoon populated by seagrasses or seaweeds. Marine of Environmental Research 52: 323-349.

Sfriso A, Facca C, Ghetti PF. 2003. Temporal and spatial changes of macroalgae and phytoplankton in a Mediterranean coastal area: the Venice lagoon as a case study. Marine Environmental Research (56)5: 617-636.

Skinner J, Zalewski S. 1995. Fonctions et valeurs des zones humides méditerranéennes. Conservation des zones humides méditerranéennes, Programme MedWet, Fondation Tour du Valat: Arles, France.

Souchu P, Gasc A, Cahet G, Vaquer A, Collos Y, Deslous-Paoli JM. 1997. Biogeochemical composition of Mediterranean waters outside Thau Lagoon. Estuarine Coastal and Shelf Science 44(3): 275-284.

Souchu P, Gasc A, Collos Y, Vaquer A, Tournier H, Bibent B, Deslous-Paoli JM. 1998. Biogeochemical aspects of bottom anoxia in a Mediterranean lagoon (Thau, France). Marine Ecology Progress Series 164: 135-146.

Succow M, Reinhold A. 1978. Das vegetationsgefüge eines jungpleistozänen Klarwassersees und seine Belastbarkeit. Eine Studie mit Hilfe von Farbluftbildern. Limnologica 11(2): 355-377.

Tamisier A, Boudouresque CF. 1994. Aquatic bird populations as possible indicators of seasonal nutrient flow at Ichkeul lake, Tunisia. Hydrobiologia 279/280: 149-156.

Terrados J, Ros JD. 1992. Growth and primary production of Cymodocea nodosa (Ucria) Ascherson in a Mediterranean coastal lagoon: the Mar Menor (SE Spain). Aquatic Botany 43: 63-74.

Traer K. 1980. The consumption of Posidonia oceanica Delile by echinoids at the isle of Ischia. In Echinoderm: Present and Past, Jangoux M (ed.). Balkema: Rotterdam; 241-244. 
Verhoeven JTA. 1980. The ecology of Ruppia - dominated communities in western Europe. III. Aspects of production, consumption and decomposition. Aquatic Botany 8: 209-253.

Vidy G. 2001. Quelques exemples d'intervention sur les lagunes et les estuaires d'Afrique de l'Ouest: avantages, conséquences, leçons pour l'avenir. In Restauration des Écosystémes Côtiers, Ifremer (ed.). Colloque 8 et 9 Nov. 2000, Brest, France; 179-195.

Whittaker RH. 1975. Communities and Ecosystems, 2nd edn. Macmillan: London.

Woodwell GM, Rich PH, Hall CSA. 1973. Carbon in estuaries. In Carbon in the Biosphere, Woodwell GM, Pecan EV (eds). US Department of Commerce: Springfield, VA; 221-240.

Zar JH. 1984. Biostatistical analysis, 2nd edn. Prentice-Hall: Englewood Cliffs, NJ. 